\title{
PERBEDAAN FREKUENSI DENYUT JANTUNG JANIN BERDASARKAN PARITAS DAN USIA KEHAMILAN
}

\author{
Nur Chabibah ${ }^{1}$, Emi NurLaela ${ }^{2}$ \\ email: nchabibah@ymail.com \\ ${ }^{1,2}$ STIKES Muhammadiyah Pekajangan Kabupaten Pekalongan 51172, Indonesia \\ Telp (0285) 785783
}

\begin{abstract}
Abstrak
Denyut jantung janin (DJJ) dianggap sebagai faktor untuk mengukur kesejahteraan janin dalam rahim. Salah satu faktor yang mempengaruhi DJJ di antaranya yaitu kecemasan selama kehamilan. Kecemasan yang dirasakan ibu hamil sesuai dengan pengalaman yang pernah dirasakannya dan sesuai tahap perkembangan psikologis pada masa kehamilan. Tujuan penelitian ini yaitu untuk menganalisa frekuensi denyut jantung janin berdasarkan paritas dan usia kehamilan. Desain penelitian cross sectional, dengan pendekatan Observational. Teknik pengambilan sampel menggunakan cluster random sampling, di Wilayah Kerja Puskesmas Wiradesa, sebanyak 72 responden. Hasil penelitian diperoleh bahwa terdapat perbedaan denyut jantung janin ibu hamil primigravida dan multigravida yang signifikan secara statistik dan klinis ( $\mathrm{p}$-value $=0.000, \mathrm{CI}=8.15-5.45$ ). Demikian juga untuk denyut jantung janin yang dibedakan menurut usia kehamilan, terdapat perbedaan yang bermakna baik secara klinis maupun statistik denyut jantung janin pada kehamilan trimester 2 dan kehamilan trimmester 3 ( $\mathrm{p}$-value $=0.047, \mathrm{CI}=0.04-8.11$ ). Saran untuk tenaga kesehatan, agar memberikan asuhan sesuai dengan status paritas dan umur kehamilan, khususnya ibu hamil dengan faktor resiko, yang harus dilakukan pemantauan lebih lanjut sehingga kemungkinan ketidaknormalan atau komplikasi kehamilan dapat dideteksi, terutama melalui pemeriksaan denyut jantung janin.
\end{abstract}

Kata kunci: Frekuensi, Denyut jantung, Paritas

\section{Pendahuluan}

Angka kematian bayi merupakan indikator yang penting untuk mengukur derajat kesehatan suatu negara. Hal ini karena bayi sangat rentan terhadap keadaan kesehatan atau kesejahteraan yang buruk. ${ }^{1}$ Salah satu cara untuk menurunkan angka kematian perinatal yang disebabkan oleh penyulit-penyulit hipoksia janin dalam rahim antara lain dengan melakukan pemantauan kesejahteraan janin. $^{2}$ Tujuan pemantauan janin adalah untuk mendeteksi dini ada tidaknya faktor-faktor resiko kematian prenatal tersebut (hipoksia/asfiksia, gangguan pertumbuhan, cacat bawaan, dan infeksi). ${ }^{3}$

Frekuensi denyut jantung janin pada usia 25 minggu adalah $150 \mathrm{x} /$ menit. $^{4}$ sedangkan pada saat aterm adalah 110-150x/menit, dan sebelum akhir periode tersebut, 160 kali/ menit dianggap sebagai batas maksimum frekuensi denyut jantung normal. Namun, belum ada penelitian yang menyebutkan frekuensi DJJ secara spesifik pada kehamilan primigravida maupun multigravida. Dan nilai normal denyut jantung janin antara 120-160 kali permenit. $^{2}$ Denyut jantung janin dasar menurun tajam seiring peningkatan usia gestasi sebagai akibat maturnya tonus parasimpatis. Pemeriksaan denyut jantung janin diukur 1 menit penuh. ${ }^{4}$ Namun pada kenyataan di lapangan sering ditemukan pengukuran DJJ pada pemeriksaan kehamilan hanya untuk mengetahui ada tidaknya bunyi, tanpa mengetahui frekuensinya, sehingga tidak bisa mendeteksi jika ada kemungkinan ketidakteraturan atau frekuesinya lebih kecil dari 110, dan lebih besar dari 160. DJJ kurang dari 110x/menit dianggap sebagai bradikardia janin. Sedangkan pada kondisi takhikardia janin apabila terjadi peningkatan frekuensi DJJ di atas 160x/menit, yang disebabkan oleh berbagai factor, di antaranya hipoksia janin, anemia, dan obat-obatan. ${ }^{5}$

\section{Metode Penelitian}

Penelitian ini merupakan penelitian study komparatif. Desain penelitian yang digunakan dalam penelitian ini adalah cross sectional, 
dengan pendekatan Observational, yaitu peneliti melakukan pengamatan secara langsung terhadap objek yang diteliti, dengan melakukan pemeriksaan denyut jantung.

Teknik pengambilan sampel yang dilakukan pada penelitian ini yaitu dengan Cluster Random Sampling. Dari 16 desa yang ada di wilayah kerja puskesmas Wiradesa, yaitu 3 desa dari 16 desa yang berada di Wilayah Kerja Puskesmas Wiradesa Kabupaaten Pekalongan. Sampel dalam penelitian ini sebanyak 77 dengan kriteria inklusi Ibu hamil primigravida dan multigravida dengan umur kehamilan lebih dari 20 minggu atau 5 bulan yang ada di desa Kecamatan Wiradesa yang berada di wilayah kerja Puskesmas Wiradesa.

Data bivariable dianalisa dengan menggunakan uji $t$ tes independent dengan tingkat kemaknaan yang digunakan pada uji ini adalah $p$-value <0.05 pada intervensi kepercayaan $95 \%$.

\section{Hasil dan Pembahasan}

Penelitian dilakukan pada 77 responden. Hasil pengukuran denyut jantung janin bedasakan paritas dan usia kehamila sebagai berikut:

Tabel 1. Distribusi Frekuensi Denyut jantung janin Berdasarkan Paritas

\begin{tabular}{cccc}
\hline $\begin{array}{c}\text { Status } \\
\text { Paritas }\end{array}$ & Mean & SD & Min-Max \\
Primigravida & 137,81 & 2,374 & $131-143$ \\
Multigravida & 144,61 & 2,998 & $139-151$ \\
\hline
\end{tabular}

Hasil pengukuran pada ibu hamil primigravida adalah 137,81 x/menit ibu hamil multigravida adalah 144,61 x/menit. Hal ini menunjukkan bahwa nilai denyut janung janin lebih tinggi pada ibu hamil multigravida.

Tabel 2. Distribusi Frekuensi Denyut jantung janin Berdasarkan Usia Kehamilan

\begin{tabular}{cccc}
\hline Trimester & $\mathbf{n}$ & Mean DJJ & SD \\
2 & 5 & 145 & 3,74 \\
3 & 67 & 141 & 4,39 \\
\hline
\end{tabular}

Berdasarkan hasil penukuran rata-rata denyut jantung janin pada ibu hamil trimester 2 adalah $145 \mathrm{x} /$ menit sedangkan untuk ibu hamil trimester 3 adalah $141 \mathrm{x} /$ menit. Hal ini menunjukkan bahwa nilai denyut janung janin lebih tinggi pada ibu hamil ibu hamil trimester 2.

Tabel 3. Perbedaan Frekuensi Denyut Jantung Janin Berdasarkan Paritas Dan Usia Kehamilan

\begin{tabular}{lcccc}
\hline Variabel & Mean \pm SD & \multirow{\rho}{\rho}{} & $\Delta$ CI 95\% \\
\cline { 2 - 4 } & Primi & Multi & value & \\
\hline Paritas & 138 & 145 & 0.000 & $8.15-5.45$ \\
\hline & TM 2 & TM3 & & \\
\hline $\begin{array}{l}\text { Usia } \\
\text { hamil }\end{array}$ & 145 & 141 & 0.047 & $0.04-8.11$ \\
\hline
\end{tabular}

Perbedaan denyut jantung janin pada ibu hamil primigravida dan multigravida signifikan secara statistik dengan melihat nilai p-value $<0.05$ (p-value $=0.000, \mathrm{CI}=8.15-$ 5.45). Sedangkan jika melihat perbedaan nilai mean sebesar 7x/menit. Jadi dapat disimpulkan bahwa ada perbedaan yang signifikanantara denyut jantungjanin ibu hamil primigravida dengan denyut jantung janin ibu hamil multigravida.

Denyut jantung janin yang dibedakan menuru $t$ usia kehamilan berdasarkan trimester kehamilan memperlihatkan nilai $\mathrm{p}$ value $<0.05$ (p-value $=0.047, \mathrm{CI}=0.04$ 8.11). Nilai selisih mean antara denyut jantung janin pada trimester 2 dan trimester 3 sebesar $407 \mathrm{x} /$ menit. Sehingga dapat disimpulkan bahwa ada perbedaan yang signifikan baik secara klinis maupun secara statistik antara denyut jantung janin pada kehamilan trimester 2 dan trimester 3 .

Hasil analisa frekuensi denyut jantung janin pada kehamilan primigravida menunjukkan 14 dari 36 ibu hamil primigravida menghasilkan frekuensi denyut jantung janin $137 \mathrm{x} / \mathrm{menit}$ yaitu $38.88 \%$ dengan rata-rata frekunsi $137.81 \mathrm{x} /$ menit. Hal ini menunjukkan DJJ tersebut masih dalam rentang normal dan kesejahteraan janin yang baik, karena nilai normal DJJ yaitu 120-160 $\mathrm{x} /$ menit. $^{3}$

Berbeda dengan primigravida, hasil penelitian yang dilakukan kepada ibu hamil multigravida menunjukkan 13 dari 36 ibu hamil multigravida menghasilkan frekuensi 
denyut jantung janin $143 \mathrm{x} /$ menit yaitu 36,1\% dengan rata-rata frekuensi $144.61 \mathrm{x} /$ menit. Hal ini menunjukkan DJJ tersebut masih dalam rentang normal dan kesejahteraan janin yang baik.

Denyut jantung janin dipengaruhi berbagai faktor, di antaranya yaitu posisi ibu, aktivitas uterus, dan umur kehamilan ibu yang diakibatkan kesimbangan kematangan saraf simpatis dan parasimpatis, stress janin, dan kecemasan yang dirasakan oleh ibu hamil. ${ }^{6}$

Pada primigravida sendiri, terjadi sejumlah perubahan baik fisik maupun psikologi. Pada perubahan fisik di antaranya yaitu perubahan uterus yang diakibatkan meregangnya uterus oleh janin yang menjadikan uterus lebih tegang dari kehamilan multigravida. ${ }^{7}$ Ditinjau dari segi psikologi, juga nampak perubahan yang terjadi. Perubahan psikologinya cenderung kepada kecemasan yang ibu rasakan karena perubahan fisik yang sangat signifikan dan kecemasan terhadap kondisi bayi yang dikandungnya. ${ }^{8}$ Kecemasan inilah yang bisa menjadikan ibu mengalami masalah ketidaknyamanan fisik selama kehamilan, yang mengakibatkan ibu tidak memperhatikan kehamilannya, termasuk asupan nutrisi, yang kurang. Asupan nutrisi yang kurang pada ibu juga akan mengakibatkan janin tidak mendapatkan nutrisi dengan baik, sehingga aliran darah ke janin pun berkurang, yang dapat mengakibatkan denyut jantung janin rendah.

Hal ini terlihat pada hasil penelitian yang menunjukkan bahwa rata-rata denyut jantung janin pada primigravida cenderung lebih rendah daripada multigravida, tetapi masih dalam rentang yang normal. Selain karena faktor asupan nutrisi, penurunan DJJ ini bisa diakibatkan karena kontraksi uterus. Kurniawan menerangkan, bahwa jika pengukuran DJJ dilakukan pada saat perut dalam keadaan kontraksi, maka hasil frekuensi DJJ cenderung meningkat atau menurun. Keadaan DJJ menurun jika terdapat penekanan pada kepala janin, tali pusat, dan pembuluh darah miometrial menjelang persalinan. Dalam penelitian ini ibu hamil yang diperiksa tidak dalam keadaan kontraksi, tetapi kondisi uterusnya distensi, sehingga mengakibatkan penurunan denyut jantung janin, tetapi masih dalam rentang yang normal. ${ }^{6}$

Rata-rata frekuensi denyut jantung janin pada kehamilan multigravida lebih tinggi daripada primigravida. Hal ini kemungkinan disebabkan pada kehamilan multigravida kondisi psikologi ibu yang baik, dan kecemasan terhadap kehamilan berkurang, sehingga ibu memiliki kesiapan mental yang lebih baik karena pengalaman yang sudah ibu rasakan pada kehamilan sebelumnya. ${ }^{9}$ Kesiapan mental yang baik ini juga menjadikan ibu hamil multigravida bisa memperhatikan asupan nutrisinya, sehingga nutrisi janin baik, dan aliran darah intervili pun baik. Jika ditinjau dari kondisi uterusnya, uterus multigravida lebih lembek dari primigravida, karena uterus sudah pernah terisi oleh janin sebelumnya, sehingga lebih kendur.

Wiknjosastro mengungkapkan makin
tinggi paritas, makin kurang baik
endometrium di sekitar implantasi kurang sempurna, maka pemberian zat-zat makanan pada hasil konsepsi terganggu dan dapat menyebabkan kelainan pada pertumbuhan hasil konsepsi (kematian janin atau cacat). ${ }^{2}$ Namun, pada penelitian terhadap ibu hamil multigravida, denyut jantung janin masih menunjukkan nilai normal. Hal ini menunjukkan endometrium yang masih baik dan tempat implantasinya masih baik, sehingga sirkulasi uteroplasenter ke janin pun lancar, yang menyebabkan hasil DJJ baik, dan masih dalam rentang normal. Hal ini dikarenakan responden multigravida yang diteliti paritasnya tidak lebih dari 3, sehingga fungsi endometrium masih baik dan kesejahteraan janin yang baik.

\section{Kesimpulan}

Hasil penelitian menunjukkan ada perbedaan yang signifikan antara frekuensi denyut jantung janin pada ibu hamil primigravida dengan ibu hamil multigravida 
dan pada kehamilan di trimester 2 dan trimester 3, Sehigga tenaga kesehatan diharapkan dapat memberikan asuhan yang sesuai, khususnya ibu hamil yang memiliki fakor resiko dalam hal ini grandemultipara dan asuhan yang lebih intensif pada trimester 3 , terkait kecemasan ibu mejelang proses persalinan. Pemantauan kesejahteraan janin secara berkelanjutan diperlukan untuk medeteksi kemungkinan ketidaknormalan atau komplikasi kehamilan.

\section{Daftar Pustaka}

[1] Baston, Hellen \& Jennifer Hall, (2012), Antenatal, EGC, Jakarta

[2] Bobak, Lowderwiilk \& Jensen, (2005), Keperawatan maternitas, EGC, Jakarta

[3] Dinkes Kab.Pekalongan, (2012), PWS KIA tahun 2012, Tidak dipublikasikan, Pekalongan.

[4] Gondo, Harry Kurniawan \& Tjokorda Gde Agung Suwardewa, (2011), Kardiotokografi, mengerti dan memahami pemanatauan denyut jantung janin, EGC, Jakarta

[5] Holmes, Debbie \& Baker, Philip N, (2008), Ilmu kebidanan, EGC, Jakarta

[6] Manuaba, Ida Bagus Gde (2010), Ilmu kebidanan, penyakit kandungan, dan KB untuk pendidikan bidan, EGC, Jakarta.

[7] Saifudin, Abdul Bari (2009), Ilmu kebidanan, PT Bina Pustaka Sarwono Prawirohardjo, Jakarta.

[8] Utami, Agnita (2012), Perbedaan tingkat kecemasan primigravida dengan. multigravida dalam menghadapi kehamilan, dilihat pada 14 Juni 2013, <http://
ejournal.unri.ac.id/index.php/JNI/article /download/643/636>.

[9] Winkjosastro, Hanifa (2011), Ilmu kebidanan, PT Bina Pustaka Sarwono Prawirohardjo, Jakarta 